\title{
GAMBARAN TEKANAN DARAH PADA REMAJA OBES DI KABUPATEN MINAHASA
}

\author{
${ }^{1}$ Rosie Tooy \\ ${ }^{2}$ Aaltje Manampiring \\ ${ }^{2}$ Fatimawali
}

\author{
${ }^{1}$ Kandidat skripsi Fakultas Kedokteran Universitas Sam Ratulangi Manado \\ ${ }^{2}$ Bagian Kimia Fakultas Kedokteran Universitas Sam Ratulangi Manado \\ Email: tooy.rosie@yahoo.com
}

\begin{abstract}
The incidence of obesity continues to rise everywhere. Obesity can increase the risk of high blood pressure. For adolescents, hypertension is also a problem because adolescents with hypertension can continue in adulthood and also with higher chance of morbidity and mortality. According to the data from Riskesdas for the year 2007, the prevalence of hypertension in adolescents is $9 \%$. The Riskesdas data for the year 2010 also show that prevalence of obesity in adolescents 19,1\%. This study aims to describe the blood pressure in obese adolescents at Minahasa district. This study is crosssectional descriptive approach, with the sample amounted to 54 people. The test results found that 104 students have a waist circumference greater than a normal waist should be. Beside that, the results showed an outline of blood pressure in obese adolescents at Minahasa district is $29,62 \%$ that has hypertension. There are 16 subjects from 54 subjects studied had the blood pressure greater than normal limits while 38 subjects studied had blood pressure within normal limits.
\end{abstract}

Keywords: Blood Pressure, Obesity

\begin{abstract}
Abstrak: Angka kejadian obesitas terus meningkat dimana-mana. Obesitas dapat meningkatkan resiko terjadinya penyakit darah tinggi. Pada remaja, hipertensi juga merupakan suatu masalah, oleh karena remaja yang mengalami hipertensi dapat terus berlanjut pada usia dewasa dan memiliki resiko morbiditas dan mortalitas yang lebih tinggi. Menurut data Riskesdas tahun 2007, prevalensi hipertensi pada remaja sebesar 9\%. Prevalensi obesitas pada remaja menurut data Riskesdas 2010 sebesar 19,1\%. Penelitian ini bertujuan untuk mengetahui gambaran tekanan darah pada remaja obes di kabupaten Minahasa. Penelitian ini bersifat cross-sectional dengan pendekatan deskriptif. Sampel penelitian ini berjumlah 54 orang. Hasil pemeriksaan didapati 104 siswa yang memiliki lingkar pinggang lebih dari normal. Hasil penelitian menunjukkan gambaran tekanan darah pada remaja obes di kabupaten Minahasa didapatkan 29,62\% yang menderita hipertensi. Terdapat 16 subjek dari 54 subjek yang diteliti memiliki tekanan darah lebih dari batas normal sedangkan 38 subjek memiliki tekanan darah dalam batas normal.
\end{abstract}

Kata kunci: Obesitas, Tekanan Darah

Tekanan darah merupakan salah satu masalah kesehatan di dunia, termasuk di Indonesia. Tekanan darah normal yaitu 120/80 mmHg, jika melebihi batas normal, tekanan darah tersebut tergolong tekanan darah tinggi atau hipertensi. Di Indonesia, prevalensi penyakit hipertensi pada orang dewasa cukup tinggi. Berdasarkan pengukuran tekanan darah, prevalensi hipertensi di Indonesia adalah 32,2\%, sedangkan prevalensi hipertensi berdasarkan diagnosis oleh tenaga kesehatan dan atau riwayat minum obat hanya $7,8 \%$ atau hanya 24,2\% dari kasus hipertensi di masyarakat. Berarti 75,8\% kasus hipertensi di Indonesia belum terdiagnosis dan terjangkau pelayanan kesehatan. ${ }^{21}$ Pada remaja hipertensi juga merupakan suatu masalah, oleh karena 
remaja yang mengalami hipertensi dapat terus berlanjut pada usia dewasa dan memiliki risiko morbiditas dan mortalitas yang lebih tinggi. Walaupun prevalensi secara klinis sangat sedikit pada anak dan remaja dibanding pada dewasa, namun cukup banyak bukti yang menyatakan bahwa hipertensi esensial pada orang dewasa dapat berawal pada masa kanakkanak dan remaja. ${ }^{1}$

Menurut Riskesdas tahun 2007 di Indonesia, prevalensi hipertensi pada remaja sebesar 9\%. Prevalensi obesitas pada remaja menurut Riskesdas 2010 sebesar 19,1\%. ${ }^{2}$ Angka kejadian hipertensi meningkat sesuai dengan usia, berkisar 15\% pada usia dewasa muda hingga 60\% pada orang yang berusia 65 tahun ke atas. ${ }^{1}$

Obesitas meningkatkan resiko terjadinya penyakit tekanan darah tinggi. Obesitas saat ini disebut sebagai The New World Syndrome, angka kejadiannya terus meningkat dimana-mana. Di seluruh dunia, kini dilaporkan ada lebih dari satu miliar orang dewasa dengan berat badan lebih (gemuk), dan paling sedikit ada 300 juta orang yang masuk kategori obesitas. "Di setiap wilayah di dunia, obesitas meningkat dua kali lipat antara tahun 1980 dan 2008," kata Dr Ties Boerma, Direktur Departemen Statistik Kesehatan dan Sistem Informasi di WHO (Mei 2012). Tingkat obesitas tertinggi berada di wilayah WHO dari Amerika (26\% orang dewasa) dan terendah di wilayah WHO Asia Tenggara (3\% obesitas). ${ }^{3}$ Penelitian di Semarang pada tahun 2004 memperlihatkan bahwa prevalensi overweight pada remaja adalah 9,1\% sedangkan obesitas $10,6 \% .{ }^{20}$ Dalam semua bagian dunia, perempuan lebih cenderung menjadi gemuk daripada laki-laki, dan dengan demikian beresiko lebih besar terkena diabetes, penyakit jantung dan beberapa jenis kanker. $^{3}$

Di Indonesia, dapat dikatakan lebih dari seperempat penduduk memiliki berat badan berlebihan. Ini disebabkan karena konsumsi makanan yang tinggi karbohidrat sehingga kemungkinan memiliki resistensi insulin lebih besar. Begitupun masyarakat Minahasa yang sangat dikenal dengan pola konsumsi makanan yang mengandung asam lemak jenuh tinggi. Kebiasaan makan dipengaruhi oleh factor budaya, adat istiadat, agama dan kepercayaan. ${ }^{4}$ Peran kebiasaan makan tersebut turut menentukan dalam proses terjadinya obesitas dan penyakit hipertensi yang dapat terjadi pada siapa saja bukan hanya orang dewasa, tetapi juga pada remaja di Minahasa.

Berdasarkan latar belakang di atas, peneliti merasa tertarik untuk melakukan penelitian mengenai gambaran tekanan darah pada remaja obes di kabupaten Minahasa.

\section{METODE PENELITIAN}

Penelitian ini bersifat cross-sectional dengan pendekatan deskriptif. Penelitian dilakukan di SMK Negeri 2 Tondano dan SMK Negeri 3 Tondano antara bulan Agustus 2012 - Januari 2013. Populasi adalah remaja yang berusia 13 sampai 18 tahun di Tondano. Sampel adalah siswa SMK Negeri 2 dan SMK Negeri 3 Tondano yang tergolong obesitas. Pemilihan sampel menggunakan cara Simple Random Sampling. Kriteria inklusi yaitu siswa yang berusia 13 sampai 18 tahun, sehat, terdaftar dan aktif mengikuti kegiatan di sekolah dan siswa yang bersedia menandatangani surat persetujuan untuk dijadikan sampel penelitian. Kriteria eksklusi yaitu siswa yang menderita penyakit kronis dan siswa yang mengkonsumsi obat-obatan yang dapat mempengaruhi tekanan darah. Definisi operasional tekanan darah adalah hasil pengukuran yang diukur dengan menggunakan sphygmomanometer dan stetoskop. Remaja adalah individu yang berusia 13-18 tahun (Hurlock,1981). Obesitas adalah suatu keadaan patologis, dimana lingkar perut yang diukur melebihi batas normal. Lingkar perut $\geq 90 \mathrm{~cm}$ pada laki-laki dan $\geq 80 \mathrm{~cm}$ pada perempuan dinyatakan obesitas sentral. Indeks Massa Tubuh menurut CDC $2000 \geq$ persentil ke-95. Instrumen penelitian yang digunakan antara lain: timbangan, alat pengukur tinggi badan, meteran, stetoskop, sphygmomanometer. Cara kerja untuk mengukur Obesitas Sentral yaitu diukur 
dalam posisi berdiri tegak dan tenang. Baju atau penghalang pengukuran disingkirkan. Letakkan pita pengukur di tepi atas crista iliaca. Yakinkan bahwa pita pengukur tidak menekan kulit terlalu ketat dan sejajar dengan lantai. Pengukuran dilakukan saat akhir ekspirasi normal. Nyatakan lingkar pinggang dalam $\mathrm{cm}$. Cara mengukur tekanan darah yaitu diukur dalam posisi duduk pada lengan kanan setelah subjek duduk tenang minimal 15 menit. Lengan kanan sedikit flexi, lengan atas setinggi jantung. Lengan baju disingkirkan kemudian pasang manset yang lebarnya dapat melingkari sekurangkurangnya 2/3 panjang lengan atas dan tidak boleh menempel baju. Stetoskop diletakkan di fossa cubiti dengan terlebih dahulu dilakukan palpasi arteri untuk mendapat posisi stetoskop yang tepat. Pemompaan dilakukan hingga 20-30 $\mathrm{mmHg}$ di atas tekanan waktu denyut arteri radialis tidak teraba. Pengempesan dilakukan dengan kecepatan 2-3 mmHg tiap detik. Tekanan sistolik dinyatakan dengan korotkoff I dan tekanan diastolik dengan korotkoff $\mathrm{V}$. Pengukuran dilakukan sebanyak dua kali untuk mengambil rata-ratanya dengan selisih waktu pengukuran 5 menit. Data yang diperoleh kemudian dikumpulkan dan diolah untuk mendapatkan karakteristik dan gambaran tekanan intraokular pada pemain musik bia yang kemudian disajikan dalam bentuk tabel distribusi frekuensi.

\section{HASIL PENELITIAN}

Penelitian dilakukan sejak bulan Agustus 2012-Januari 2013 di SMK Negeri di Kota Tondano. Pada awal penelitian peneliti terlebih dahulu membuat surat persetujuan penelitian yang ditandatangani oleh Kepala Dinas Pendidikan Pemuda dan Olahraga di Kota Tondano. Kemudian surat tersebut diserahkan kepada kepala sekolah SMK Negeri di Kota Tondano untuk mendapatkan izin agar dapat melaksanakan penelitian di sekolah tersebut.

Penelitian yang dilakukan di SMK Negeri di Tondano terdapat 1677 orang siswa yang terdiri dari laki-laki dan perempuan. Kemudian peneliti melakukan pemeriksaan obesitas dengan mengukur lingkar pinggang. Siswa yang mengikuti pemeriksaan obesitas adalah 395 orang siswa sedangkan siswa yang tidak mengikuti pemeriksaan lingkar pinggang adalah 1282 orang. Siswa yang tidak mengikuti pemeriksaan obesitas dikarenakan siswasiswa tersebut tidak masuk sekolah berhubung tidak ada lagi kegiatan belajarmengajar. Setelah dilakukan pengukuran ditemukan 104 orang siswa obes, sedangkan 291 orang siswa tidak obes. Kemudian 54 orang siswa obes yang bersedia mengikuti pemeriksaan tekanan darah sebagai sampel, yang terdiri dari 11 orang siswa laki-laki dan 43 orang siswa perempuan.

Tabel 1, menunjukkan dari 395 orang remaja yang diukur lingkar pinggangnya ditemukan 104 orang remaja yang mengalami obesitas, terdiri dari 17 orang remaja lakilaki (4,30\%) dan 87 orang remaja perempuan (22,03\%), sedangkan untuk 291 (73,67\%) siswa yang lain yang diukur lingkar pinggangnya tidak mengalami obesitas atau memiliki berat badan yang normal.

Tabel 2, menunjukkan dari 54 sampel yang diteliti, 5 siswa laki-laki dan 9 siswa perempuan dengan jumlah 14 siswa (25,92\%) yang tergolong memiliki tekanan darah sistolik lebih dari normal dan 4 siswa laki-laki dan 9 siswa perempuan dengan jumlah 13 siswa (24,07\%) memiliki tekanan darah diastolik lebih dari normal. Dan 6 siswa laki-laki dan 32 siswa perempuan dengan jumlah 38 siswa (70,37\%) yang tergolong memiliki tekanan darah yang normal. Dari 54 sampel yang diteliti yaitu 11 siswa laki-laki dan 43 siswa perempuan semuanya memiliki lingkar pinggang lebih dari normal. 
954 Jurnal e-Biomedik (eBM), Volume 1, Nomor 2, Juli 2013, hlm. 951-955

Tabel 1. Prevalensi obesitas pada remaja di Kabupaten Minahasa

\begin{tabular}{cccccc}
\hline No & Jenis Kelamin & $\mathrm{N}$ & \multicolumn{3}{c}{ Berat Badan } \\
\cline { 3 - 5 } & & & Normal (\%) & Obesitas (\%) & $\%$ \\
\hline 1 & Laki-laki & 129 & $112(28,35)$ & $17(4,30 \%)$ & 100 \\
2 & Perempuan & 266 & $179(45,32)$ & $87(22,03)$ & 100 \\
& Total & 395 & $291(73,67 \%)$ & $104(26,33 \%)$ & 100 \\
\hline
\end{tabular}

Tabel 2. Hasil kriteria diagnosis (Menurut IDF)

\begin{tabular}{cccc}
\hline \multirow{2}{*}{ Kriteria Diagnosis } & \multicolumn{3}{c}{ Jenis Kelamin } \\
\cline { 2 - 3 } & Laki-laki & Perempuan & Jumlah (\%) \\
\hline Tekanan Darah $(m m H g)$ & & 9 & $14(25,92)$ \\
Sistolik $\geq 130$ & 5 & 9 & $13(24,07)$ \\
Diastolik $\geq 85$ & 4 & 11 & $16(29,62)$ \\
$(\geq 130 / 85)$ & 5 & 32 & $38(70,37)$ \\
$(<130 / 85)$ & 6 & $43(>80)$ & $54(100)$ \\
Lingkar Pinggang $(\mathrm{cm})$ & $11(>90)$ & & \\
\hline
\end{tabular}

\section{BAHASAN}

Pada hasil penelitian 54 sampel yang tergolong lingkar pinggang lebih, 11 diantaranya adalah laki-laki dan 43 perempuan. Hal ini sesuai dengan penelitian yang dilakukan sebelumnya oleh Kamso pada tahun 2007 bahwa prevalensi obesitas sentral di Kota Padang didapatkan sebesar $12,1 \%$ pada pria dewasa dan $46,3 \%$ pada wanita dewasa. ${ }^{5}$

Dengan data yang diperoleh obesitas sentral cukup tinggi pada usia remaja. Hal ini mungkin disebabkan karena tingginya konsumsi makanan berlemak, rendahnya konsumsi sayuran dan buah, dan rendahnya aktivitas fisik. $^{5}$

Masa remaja adalah masa kritis terjadinya obesitas. Hal ini karena pada usia remaja terjadi perkembangan fisik dimana remaja laki-laki menginginkan bentuk fisik yang besar dan anak perempuan karena pengaruh faktor endokrin dan perubahan hormonal. ${ }^{6}$

Hasil pemeriksaan pada Tabel 4.2 dari 54 sampel yang diteliti 5 siswa $(9,25 \%)$ lakilaki dan 11 siswa (20,37\%) perempuan dengan jumlah 16 siswa (29,62\%) yang tergolong memiliki tekanan darah tinggi (hipertensi). Menurut Riskesdas 2007, prevalensi hipertensi pada remaja sebesar $9 \%{ }^{2}$ Hal ini menunjukkan bahwa hasil penelitian ini lebih tinggi dari data Riskesdas tersebut. Bila ditinjau perbandingan prevalensi hipertensi antara perempuan dan laki-laki, ternyata menunjukkan angka yang bervariasi. Hasil penelitian yang dilakukan sebelumnya oleh Irza (2009) di Sumatera Barat, hipertensi lebih banyak dialami oleh wanita (66,67\%) dibandingkan pria (33,33\%). Sedangkan daerah perkotaan di Jakarta (Petukangan) didapatkan 14,6\% pria dan 13,7\% perempuan (Sugihartono, 2007). ${ }^{7}$

Faktor resiko terjadinya hipertensi dapat dibagi menjadi dua kategori utama, yaitu faktor yang tidak dapat diubah dan faktor yang dapat diubah. Faktor resiko yang tidak dapat diubah yaitu genetis, jika mempunyai riwayat keluarga hipertensi, maka peluang untuk menderita hipertensi semakin besar. Usia juga merupakan salah satu faktor resiko yang tidak dapat diubah, walaupun penuaan tidak selalu memicu hipertensi, tekanan darah tinggi biasanya terjadi pada usia lebih tua. Selain itu, jenis kelamin juga merupakan faktor resiko yang tidak dapat diubah. Pria sering mengalami tanda-tanda hipertensi pada usia akhir tiga puluhan, sedangkan wanita sering mengalami hipertensi setelah menopause. Tekanan darah wanita, khususnya sistolik, meningkat lebih tajam sesuai usia. Salah satu penyebab terjadinya pola tersebut adalah perbedaan hormon kedua jenis kelamin.

Faktor resiko yang dapat diubah yaitu pertama kebiasaan merokok, adanya penelitian mengenai hubungan antara 
merokok dan hipertensi menunjukkan bahwa dalam waktu lima menit pengisapan rokok, tekanan sistolik subjek meningkat secara dramatis, rata-rata lebih dari 20 mmHg, sebelum secara bertahap menurun ke tingkat asli tekanan darah subjek setelah 30 menit. Hal ini berarti tekanan darah perokok melonjak berkali-kali sepanjang hari. Peningkatan ini terjadi karena nikotin, menyempitkan pembuluh darah sehingga memaksa jantung untuk bekerja lebih keras sehingga kecepatan jantung dan tekanan darah meningkat. Faktor resiko kedua yaitu obesitas. Kelebihan berat badan dan hipertensi sering berjalan beriringan, karena tambahan beberapa kilogram membuat jantung bekerja lebih keras. Orang dengan kelebihan lemak di atas pinggul (bentuk apel) lebih beresiko hipertensi, kolesterol tinggi dan diabetes. Faktor resiko ketiga yaitu asupan garam, karena seringnya mengkonsumsi makanan cepat saji yang kadar garamnya sangat tinggi. Keempat yaitu, penggunaan alkohol. Minum alkohol secara berlebihan, yaitu tiga kali atau lebih dalam sehari merupakan faktor penyebab 7\% kasus hipertensi. ${ }^{8}$

\section{SIMPULAN}

Hasil pemeriksaan dari 54 sampel yang diperiksa tekanan darahnya didapatkan 16 orang (29,62\%) yang mengalami hipertensi, yang terdiri dari 5 orang laki-laki $(9,25 \%)$ dan 11 orang perempuan (20,37\%).

\section{DAFTAR PUSTAKA}

1. Saing, J. Hipertensi Pada Remaja. Sari Pediatri. 2005; 6(4): 159-165.

2. Rabaity, A., M. Sulchan. Konsumsi gula sederhana dan aktifitas fisik sebagai factor resiko kejadian hipertensi obesitik pada remaja awal. Journal of nutrition college. 2012; 1(1): 408-420

3. WHO (World Health Organization). New data highlight increases in hypertension, diabetes incidence. 2012. Available from http://www.who.int/mediacentre/news/releas es/2012/world_health_statistics_20120516/e n/. Acessed on 26 Okt 2012.

4. Bodhy, W., A. E. Manampiring. Prevalensi sindroma metabolic pada remaja obese di kota Tomohon. Laporan penelitian itek dan seni Universitas Sam Ratulangi, Manado; 2010.

5. Sugianty Elya. Faktor resiko obesitas sentral pada orang dewasa di Sulawesi Utara, Gorontalo dan DKI Jakarta. Available from: http://iirc.ipb.ac.id/jspui/bitstream/12345678 9/11550/2/109esu.pdf. Acessed on 17 Jan 2013.

6. Manampiring, A. E., W. Bodhy. Prevalensi hiperurisemia pada remaja obese di kota Tomohon. Laporan penelitian itek dan seni Universitas Sam Ratulangi, Manado; 2011.

7. Sarasaty, R. F. Faktor-faktor yang berhubungan dengan hipertensi pada kelompok lanjut usia di kelurahan sawah baru kecamatan Ciputat, kota Tangerang Selatan. Fakultas Kedokteran Universitas Islam Jakarta; 2011.

8. Casey, A., H. Benson. Menurunkan Tekanan Darah: Bhuana Ilmu Populer; 2006. 